\title{
Surface, Distance, Depth: The Text and its Outside
}

\section{Introduction}

In this article, I will refer to the concept of poetic critique rather loosely, and certainly not with any intention to adequately capture what Friedrich Schlegel originally had in mind (cf. Schlegel 2003). While the notion is closely connected with the literary program of early German Romanticism, it is my sense that there is a special allure to it that prompts its reactivation in the context of present-day theory. In particular, the idea of poetic critique appears to me as opening up a sort of 'third space,' or functioning as a 'line of flight,' that counteracts the false alternative that has brought much of the current methodological discussions in cultural and literary studies to an effective dead-end. Indeed, if one follows much of the contemporary debate about 'critique and postcritique' (Anker and Felski 2017), one might get the impression that the choice for practitioners in literary studies is as follows: between, on the one hand, a kind of reading that is steeped in the 'hermeneutics of suspicion' (Ricœur), that is paranoid, symptomatic, judgmental, and overly moralizing, while more or less uninterested in questions of aesthetics, attachment, and form; and, on the other hand, an essentially affirmative or aestheticist reading, devoid of social or political context, that is exclusively interested in the surface of texts, in their formal properties, affective capacities, and enchanting qualities. With regard to this unsatisfactory alternative, the concept of poetic critique represents both a rejection and a displacement along the lines of the famous formula of Melville's Bartleby: "I would prefer not to." ${ }^{1}$ For what it suggests, in my understanding, is a very different encounter with art and literature - one that does not see the desire to do justice to the work of art and the goal of exploring historico-political contexts and ideological contents as an irreconcilable either/or choice. ${ }^{2}$ In other words, my use of the concept of poetic critique is meant to resist both postcritique's quasi aestheticist refusal to take into account the text's outside and the 'anti-poetic' implications of some forms of contemporary political critique.

What this text seeks to do, then, is engage with the current discourse on critique and postcritique and present an alternative. In a nutshell, the essay's goal is to use

1 According to Gilles Deleuze, the formula represents neither an affirmation nor a negation, but the "devastating" repudiation of a false choice (cf. Deleuze 1997, 71).

2 What this further entails is the insight that in order to do justice to a literary text, it is equally necessary to do justice to its outside (the famous Derridean hors-texte) too. For the idea that the text's outside must be understood as an essential dimension of the text itself, cf. Schleusener 2018a. 
the postcritical intervention as an opportunity to think anew about the proper means of engaging, simultaneously, with literature and politics, art and society. The premise here is that a return to some reductively formalist or aestheticist principle would be an unfortunate regression, but that there are better and worse ways of reading literature critically and politically. In the first chapter, I will explore the theoretical landscape of postcritique, discussing two of the major elements of the sort of 'critique of critique' most boldly represented by Rita Felski (2015): First, the claim that what makes contemporary critique so tiresome and problematic - in other words: what represents its limits - is its reliance on the logic and hermeneutics of suspicion. And second, the implicit assertion that what is wrong with critique methodologically is its taking for granted 'abstract totalities' such as society, capitalism, or modes of production - a premise postcritics typically counter by appropriating models that are more descriptive or empiricist, such as Bruno Latour's actor-network theory.

In the second chapter, I will concentrate on the distinction between symptomatic and surface reading (as drawn by Stephen Best and Sharon Marcus), discussing the theoretical premises of the latter in view of one of postcritique's prime targets, namely Fredric Jameson. As an alternative to both the short-sighted advice to merely focus on the surface of the text itself (and thereby abandon any discussion of its outside) and a strictly allegorical reading (or "rewriting") as suggested by Jameson (cf. Jameson 2002, x), I will draw attention to the work of Siegfried Kracauer and, in particular, his analysis of the 'mass ornament.' While Kracauer thoroughly investigates his subject matter's "surface-level” (Kracauer 1995, 75), he simultaneously pays attention to its socioeconomic context or constellation. Such a reading needs to operate both from up close and from a distance, like a camera repeatedly switching between close-up and long shot. Rather than focusing on the opposition between 'close' and 'deep' analysis (Love 2010) or 'latent' and 'manifest' meaning, this sort of engagement with culture, art, and literature simultaneously aims at precision (hence its closeness to the surface of its object) and distance - a distance that should neither be confused with Franco Moretti's approach of digital quantification (cf. Moretti 2013) nor with 'critical distance,' in the sense of the critic maintaining her distance in order to keep her hands clean. Instead, to look at a text from a distance here simply means that one chooses a perspective from which it is possible to also perceive its particular outside.

In my third and final chapter, I will demonstrate the effectiveness of the sort of reading outlined with respect to Kracauer in view of a concrete literary example, namely Herman Melville's Moby-Dick. Here, in distinction to the dominant (allegorical) readings of the book, I pay close attention to what is on the surface of the novel: whales and whaling. What I seek to demonstrate, however, is that this non-allegorical focus on the book's manifest subject matter does precisely not imply an abandonment of the text's outside - its socioeconomic and political context. Instead, I will draw attention to the fact that Melville's treatment of whaling is not just inextricably linked to the book's peculiar, proto-modernist aesthetic form, but also seamlessly involves the reader with questions of political economy and socioeconomic history. 


\section{Postcritique's Political Unconscious}

There is a structural obstacle that complicates any effort at responding to postcritique critically. For if one rejects postcritical claims regarding the alleged negativity, suspiciousness, self-righteousness, and parasitic nature of critical practice, how can one make sure not to get caught in a performative contradiction and confirm the accusation? As Benjamin Noys puts it:

This is the difficult spiral in which the critics of anti-critique find themselves. To engage in the critique of anti-critique is to feed and reinforce the claims of anti-critique, which suggests that critique can never escape attachment to what it criticises and ascend to a new joyous, creative, and productive alternative. To continue to engage in critique, especially the critique of anti-critique, is to feel outdated and, sometimes, miserable, two clichés that surround the critic. By definition, the critic is secondary to what they criticise, hence already dated, and dissatisfied with what they criticise, hence miserable. (Noys 2019, 31)

Obviously, this article will not be able to escape this trap. Although its aim is ultimately to present a version of critique that manifests itself as a "productive alternative," there will also be a lot of "miserable" negativity and criticizing. But if, as Eve Sedgwick claims, suspicion and paranoia are contagious (Sedgwick 2003, 127), then this malady neither spares the critic nor the post- or anti-critic. The perfect example here is Felski's The Limits of Critique, a book that seems to perform the ultimate contradiction: a sweeping attack on the hermeneutics of suspicion that - how could it be otherwise? - is motivated by suspicion; an anti-dialectical polemic that performs "a negation of a negation" (Felski 2008, 1); a lament about critique's "secondariness" that is itself utterly dependent on "words that come from elsewhere" and "the thinking of others" (Felski 2015, 121-122); ${ }^{3}$ a manifesto against the notion of totalization that subsumes Marxism, psychoanalysis, postcolonialism, deconstruction, New Historicism, and much of feminism, Gender Studies, and Queer Theory under a single category; a repudiation of the striving for "a panoramic vision of the social order" (157) that offers a panoramic vision of the theoretical landscape; an approach that rejects the desire to reveal a text's hidden meanings and hidden agendas, yet praises actor-network theory's ability to highlight what lies "hidden among thick blades of grass" (158). In short: a "critique of critique."4

To be sure, Felski is well aware of the difficulties of expressing her "dissatisfaction with critique" (192) in the appropriate (postcritical) manner. Claiming that she

3 By definition, this obviously applies to postcritique on the whole, just as it applies to countless other currents in contemporary theory that all use the prefix 'neo-' or 'post-' ('post-postmodernism' being a particularly striking example).

4 Felski of course rejects that label but confirms the difficulty of avoiding it in practice: "As a critic schooled in suspicious reading, I am hardly immune to its charms, yet I have tried, as much as possible, to avoid being drawn into a 'critique of critique.” (Felski 2015, 192) 
has "tried to avoid critiquiness by opting for different shadings of style and tone," she also acknowledges that such an attempt "can have only a partial success," for "in the act of disagreeing with certain ways of thinking, we cannot help being drawn into the negative or oppositional attitude we are trying to avoid" (192). Her book's "questioning of critique" (8) thus appears like a somewhat curious exercise: while at times it reads like an outright rebuttal bluntly denouncing "crrritique's" destructiveness (117-150) or proclaiming that “context stinks!” (151-185), there are other passages in which the whole methodological discussion becomes oddly defensive, suggesting that there is nothing wrong with critical suspicion per se, as long as it is understood to be just one of many 'uses of literature' (Felski 2008). "It is one way of reading and thinking among others: finite, limited, and fallible" (Felski 2015 , 192). At a time, then, when others have lamented an "affirmationist consensus" (Noys 2010, ix) in continental theory, and after her own book discusses an enormous array of diverse postcritical currents - from actor-network theory and the new formalism to reading practices like surface reading, just reading, or reparative reading Felski's manifesto, in its somewhat belated effort to dethrone critique, paradoxically calls for a pluralism that already exists.

This confusing mélange of fervent anti-critical polemic, wide generalization, and rhetorical maneuvering is also expressed in Felski's take on the political. Throughout her book, she argues that postcritical is not uncritical, vehemently denying that "any questioning of critique can only be a reactionary gesture or a conservative conspiracy” (Felski 2015, 8). At the same time, however, The Limits of Critique offers practically no hints as to how a postcritical engagement with politics would actually look like. ${ }^{5}$ Moreover, what is curiously lacking in the book is any meaningful discussion of the fact that many of the issues Felski raises - like the question of autonomy and form or the role of aesthetic experience - are hardly foreign to the critical tradition per se. This certainly does not mean that she has no point in drawing attention to a routinization of critical maneuvers, claims to moral superiority, or excessive suspicion in some currents of contemporary criticism and theory. But instead of analyzing the concrete conditions of these phenomena, she blames them on 'critique' as a whole, on the tradition's collective affiliation with a generalized version of the hermeneutics of suspicion. ${ }^{6}$ While she laments that in contemporary literary studies all value is assigned "to the act of reading and none to the objects read" (Felski 2008 , 3), she herself puts all the emphasis on the act of critiquing and none on

5 In fact, when the political is mentioned at all, it is typically in the form of passive-aggressive jibes against the banality of political critique. Cf. Felski 2015, 17-18: "Anyone who attends academic talks has learned to expect the inevitable question: 'But what about power?' Perhaps it is time to start asking different questions: 'But what about love?' Or: 'Where is your theory of attachment?’”

6 What should be kept in mind here is that next to Marx and Freud, Ricœur also counts Nietzsche among his "masters of suspicion" (Ricœur 1970, 33), something which complicates Felski's association of critique and the hermeneutics of suspicion with negativity. On the Nietzschean notion of affirmation - his 'affirmation of affirmation' - cf. Deleuze 1983. 
the objects of critique. But take, for instance, the recent utilization of some aspects of postmodern and critical theory in the context of rightwing populist ('post-truth') discourse (cf. Schleusener 2018b). Is the key problem of such appropriations really the hermeneutics of suspicion? Or is it the flawed political analysis underlying this methodological choice? Here, Felski's lack of differentiating between various versions of critique - which she transforms into mere cases of a uniformly suspicious hermeneutics, irrespective of whether or not their particular suspiciousness is appropriate seems to underline the limits of her own approach.

In this respect, Felski's perspective differs significantly from that of Eve Kosofsky Sedgwick, who is often described as a pioneer of postcritique. But Sedgwick's mid90s 'critique of critique' was not simply directed against routinization and predictability per se. It was also premised on the idea that the problem with a certain kind of critique was its political uselessness in a changed ideological context. For instance, she argues that a Foucauldian genealogy and critique of the welfare state - in the 1980s and 1990s advocated by New Historicists like D.A. Miller - only played into the hands of the neoliberal dismantling of health care coverage and other public services:

Since the beginning of the tax revolt, the government of the United States [...] has been positively rushing to divest itself of answerability for care to its charges, with no other institutions proposing to fill the gap. This development, however, is the last thing anyone could have expected from reading New Historicist prose, which constitutes a full genealogy of the secular welfare state that peaked in the 1960s and 1970s, along with a watertight proof of why things must become more and more like that forever. (Sedgwick 2003, 141-142)

Sedgwick, then, laments that a critique of 'disciplinary society' comes to nothing (or worse) under neoliberal circumstances, when public welfare as such is increasingly at stake. ${ }^{7}$ Along these lines, she also reflects on the relationship between the neoliberalization of American society and the practice of critique, highlighting

the dreary and routine forms of good dog/bad dog criticism, by which, like good late-capitalist consumers, we persuade ourselves that deciding what we like or don't like about what's happening is the same thing as actually intervening in its production. (Sedgwick 2006, 619)

Or similarly:

The "subversive or hegemonic?" structure of inquiry requires a wholesale reification of the status quo. One's relation to it becomes reactive, like that of a consumer: accepting or refusing this or that manifestation of it, dramatizing extremes of compulsion and voluntarity. (Sedgwick and Frank 1995, 501)

7 On this argument, cf. also Zamora and Behrent 2016. 
Despite Felski's claim that postcritical is not uncritical, these sorts of contextualization are entirely absent from The Limits of Critique. Indeed, if Sedgwick notes that, in retrospect, certain theories and theoretical attitudes of the late 1980s and 1990s, despite their pronounced radicalism, manifest themselves not as resistant to, but, to the contrary, as reflective of the realities of the new neoliberal order, one could justifiably argue that this is even more the case with the postcritical turn of the late $2000 \mathrm{~s}$. Again, this does not bear upon the (re-)emphasis of aesthetics, form, attachment, and affects per se, but rather involves what, in loose analogy to Jameson, can be called postcritique's 'political unconscious': its seeming indifference to (or non-consideration of) the political implications of its discursive positioning. ${ }^{8}$

This concerns not only postcritique's methodological choices and its tendency to sideline history, politics, and economics, but also its narrative of what is problematic about contemporary critique. For one thing, what that narrative misses is the 'great transformation' that occurred in the history of critical thought since around the time of the neoliberal revolution to which Sedgwick draws attention in her essays from the 1990s. While Felski treats Jameson as the dominant representative of contemporary critique and symptomatic analysis, what she fails to mention is the significant decline of precisely the kind of Marxism Jameson represents in the early 1980s, which saw the rise of poststructuralism and American-style cultural studies, including disciplines like gender studies, ethnic studies, and queer theory. As many authors have noted, what went along with this development was not only a growing avoidance of economic issues in cultural and critical theory, but also a shift from 'structure' to 'identity' (cf. Michaels 2006) and from 'redistribution' to 'recognition' (cf. Fraser 1995).

In the context of the postcritical turn, this development is given a whole new twist. Now, recognition, functioning as the dominant (cultural) currency in a theoretical environment that has largely abandoned structural analysis and the concept of social totality, tends to be extended to apply to the non-human realm as well. This is most obvious in the context of posthumanism and the new materialism, for example in the writings of Jane Bennett. While Charles Taylor and others had advocated respecting the identities of those who are marginalized due to their cultural difference (cf. Taylor 1992), Bennett extends this logic, calling on us to also "respect" (Bennett 2010, ix) non-human actors marginalized due to their ontological difference. Felski, having at numerous occasions voiced her sympathy for Bennett's ideas, ${ }^{9}$ goes in a similar direction. Following Latour and ANT (Felski 2015, 162-172), she places "people, animals, texts, and things on a similar ontological footing," conceptualizing art works and texts as "non-human actors" that "help to modify states of affairs," "are

8 On a related note, cf. also what Foucault has addressed in terms of the 'unthought' (Foucault 1994, 322-328).

9 For instance, Felski is quoted on the back cover of Bennett's Vibrant Matter, praising the book as “an invigorating breath of fresh air" (Bennett 2010). 
participants in chains of events," and "help shape outcomes and influence actions" (164). What she deems necessary is

a recognition - long overdue - of the text's status as a coactor: as something that makes a difference, as something that makes things happen. [...] And once we take on board the distinctive agency of art works - rather than their imagined roles as minions of opaque social forces or heroes of the resistance - we cannot help orienting ourselves differently to the task of criticism. Such a shift is desperately needed if we are to do better justice to what literature does and why such doing matters. (12-13)

Like Bennett, Felski thus attempts to restore to nonhuman actors - texts, in this case - a form of recognition that is lacking in readings in which they are subject "to interrogation" (Felski 2015, 173). The goal is "to do better justice" to texts, which implies that they were treated unjustly in the critical readings of the past. To be sure, justice is always better than injustice - and if Felski means that the reader should pay close attention to what a text says, and what it does by saying it, hardly anyone would disagree. Yet, one may again wonder about the broad generalization here: Should all texts simply be applauded for being "coactors"? Or do some, perhaps, deserve to be interrogated? And what about the specific use or function of one's reading: are diagnostic readings by definition unjust, because they link the text to "opaque social forces"? Once again, Felski does not really offer much in terms of a constructive combination of political analysis and 'close' or 'just' reading here.

Yet, in describing texts as coactors that participate "in chains of events," Felski indeed links the text to its outside, suggesting that reading and writing are not just philological activities, but that they are situated in the realm of the social - connected to, and affecting, other actors and actions, events and states of affairs. In terms of its specific concept of the social, however, Felski's network or assemblage model leaves a lot of questions open. One may ask, for instance, how, precisely, texts do what they do, and what their specific agency and role is in "what literature does." Another question may concern the role of said "opaque social forces": wouldn't they need to be included in the assemblage too - even if, as Felski suggests, they might be merely "imagined"? Or more generally, is there a way to specifically determine what needs to be included and what doesn't, and how all the assembled actors and coactors (such as authors, readers, critics, writing programs, schools, universities, bookshops, online markets, etc.) relate to each other? Are they all equally influential, or do they differ in impact and strength? And finally, what are the specific criteria for determining whether what literature does "matters" and for whether what we say about literature "does justice" to it?

The promise of a network model such as the one used here, for Felski and others, is that it allows the critic "to forgo theoretical shortcuts" (Felski 2015, 158), that is, abstract generalizations or the presupposition of the existence of "opaque social forces" (13). The problem, however, is that the task of completely avoiding such shortcuts is by definition impossible: since it is hardly feasible to include all the ac- 
tors and coactors involved in a given assemblage, any author - critic as well as postcritic - will necessarily make a selection. In principle, there is no given limit as to what a network may include, since, as Felski explains, nonhuman actors can basically be anything: "Speed bumps, microbes, mugs, baboons, newspapers, unreliable narrators, soap, silk dresses, strawberries, floor plans, telescopes, lists, paintings, can openers" (163). Consequently, a network model that desperately seeks to avoid all shortcuts and selections would simply end up with endless arbitrary enumerations, lists, or catalogues of ontologically diverse, random content. How, then, are the selections being made here? It seems that the more the author refrains from 'theoretical' shortcuts - whose principles could be discussed and refuted - the more he or she will rely on 'phenomenological' ones, that is, individual acts of apperception. Along these lines, Jane Bennett presents an assemblage in her Vibrant Matter that includes the following items:

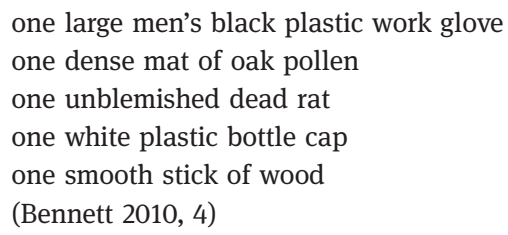

From the perspective of a postcritical theory, the advantage of this image (or poetic collage) is certainly its concreteness, its 'close' or 'thick' description of what is concretely given, what is perceived by the subject at a specific point in time and space in Bennett's case, on "a sunny Tuesday morning on 4 June in the grate over the storm drain to the Chesapeake Bay in front of Sam's Bagels on Cold Spring Lane in Baltimore" (4). From the perspective of a political ecology - which Bennett's approach imagines itself to be - there is, however, something deeply frustrating about the commitment to remain on this empirical surface-level of things, without connecting concrete objects, items, and devices to the 'abstract machines' that are involved in their production, distribution, and consumption. This is precisely what characterizes the ecological politics of Bennett's book as a posthumanist version of the "politics of recognition': trash, Bennett writes, is not simply “dead stuff” (5) but should be conceptualized as animate or active 'vital matter'; she therefore recommends that we should be more mindful of how we engage with things, matter, objects, junk. What the book does not include, however, is any serious analysis of the causes, conditions, course, and scale of the current ecological crisis - and of an effective politics that would potentially be able to resolve it.

This draws attention to what, in reference to Felski, we may call the limits of postcritique. It appears that these limitations are a general issue in theoretical currents that rely on Latour and ANT - and it is here where the charge of political quietism (cf. Robbins 2017) and compliance with the neoliberal status quo (cf. Michaels in this 
volume) can indeed claim some validity. ${ }^{10}$ This is not to say that actor-network theory is without merit, especially not since Latour can be credited for reintroducing a version of the (now ubiquitous) concept of materiality into the humanities, at a time when the focus was almost exclusively on discourse, signs, and signification. Nevertheless, it is his deliberately 'flat' topography of the social - which seems to conflate the commitment to an egalitarian ontology with an accurate description of social reality - that often contributes to an oversimplified understanding of systemic asymmetries, political conflict, and the constitution of social regularities. ${ }^{11}$ Still, Latour's dismissal of the concept of social totality is a key point of reference in the postcritical discourse: "For Latour [...] there is no historical box and no society, if we mean by this term a bounded totality governed by a predetermined set of structures and functions" (Felski 2015, 157). The idea of totality, however, against which Felski and other postcritics polemicize, had already been defeated with the rise of poststructuralism in the early 1980s. Hence, when Martin Jay wrote Marxism and Totality (1984), a wideranging account of the diverse history of the concept, he did so "in a tragic or satiric mode" (20), discussing its decline in an epilogue entitled "The Challenge of PostStructuralism" (510-537). Yet, while some authors related to poststructuralism were careful not to dismiss the notion tout court, ${ }^{12}$ Latour and his followers made sure to eradicate the last remnants of it, directing their focus exclusively towards concrete (human and nonhuman) actors and assemblages. Now, in a strange echoing of Margaret Thatcher's neoliberal dictum that there's no such thing as society (cf. Latour 2005, 5), to even use fairly familiar 'shortcuts' like capitalism, society, or mode of production comes under suspicion (pun intended). "Like God,” writes Latour, “capitalism does not exist" (Latour 1993, 173). And: "It is no longer clear whether there exists [sic] relations that are specific enough to be called 'social' and that could be grouped together in making up a special domain that could function as 'a society"' (Latour 2005, 2).

To be sure, postcritique's all-too-ready adoption of ANT's polemic against the concept of totality may, in the late 2000s, seem a bit like flogging a dead horse. The point in time, however, is significant. For the late 2000s not only saw the rise of postcritique in academic discourse, they were also in many ways informed by the experience of the global financial and economic crisis of 2008. This event which started with a seemingly isolated depreciation in the American subprime mortgage market that led to the then deepest global economic downturn since the Great

10 There are, however, various attempts at adopting aspects of actor-network theory for a left politics. As one example, cf. Mitchell 2013.

11 Cf. Robbins 2017, 374: "Latour's signature example for actor-network theory, and one that Felski repeats, is the modest speed bump. [...] It is the allegory of a social world where all the infractions are minor - where some people may want to drive too fast, but there are no malevolent intentions, there is no collective coercion, there is no systemic injustice."

12 Deleuze, for example, preferred to speak of "nodes of totalization" (Deleuze 1995, 86). 
Depression $^{13}$ - has evidently contributed to a certain resurgence not only of the concept of totality in critical discourse, but also of the general engagement with economic issues and Marxist theory in some sections of the humanities, including cultural and literary studies. ${ }^{14}$ Against this backdrop, it may not require too suspicious a reader to assess the interventions of postcritique - including its adoption of ANT's concept of the social - not just in view of their philological methodology, but also in terms of their political implications.

\section{Close-Up and Long Shot}

As another instance of the postcritical turn, I will now focus on Marcus and Best's concept of surface reading - articulated in their introduction to a 2009 special issue of Representations - which ties in well with the previously discussed new materialist version of a politics of recognition: the tendency to focus on, and champion, the concretely given (actual actors, objects, and relations) over abstract totalizations or adversarial decryptions. Along these lines, Marcus and Best argue that readers should concentrate on the 'surface' of texts, rather than reading them 'symptomatically' by attempting to uncover their hidden depths and latent meanings:

[W]e take surface to mean what is evident, perceptible, apprehensible in texts; what is neither hidden nor hiding; what, in the geometrical sense, has length and breadth but no thickness, and therefore covers no depth. A surface is what insists on being looked at rather than what we must train ourselves to see through. (Best and Marcus 2009, 9)

While Felski has stated that she shares Marcus and Best's reservations about routinized attempts at "deciphering hidden meaning," she claims that the problem of a suspicious hermeneutics is not restricted to symptomatic approaches: "an interest in surfaces does not automatically free us from the straitjacket of suspicion” (Felski 2015, 55-56). Nevertheless, there are obvious overlaps between the two approaches. One of them is the status of Fredric Jameson, who functions, for Marcus and Best as well as for Felski, as the perhaps central antagonist. In Marcus and Best's case, the twenty-fifth anniversary of the publication of The Political Unconscious (1981) was in fact constitutive of their idea to devote an entire special issue to the concept of sur-

13 It is possible that the current Covid-19 pandemic will have even more severe effects on the world economy. What the two events have in common is that they both reveal how today any incident, however local and seemingly insignificant, is ultimately embedded in the totality of social and economic relations that constitute what Immanuel Wallerstein has conceptualized as the 'world-system' (cf. Wallerstein 2004).

14 On the resurgence of the concept of totality, cf., for example, the perspective of Toscano and Kinkle (2015), whose point of departure is not Hegel's Absolute Spirit or the idea of an unbroken god'seye-view, but Jameson's notion of 'cognitive mapping' (cf. Jameson 1988). 
face reading, thereby seeking to render obsolete the approach attributed to Jameson, symptomatic reading.

Despite the loss in significance of Marxist criticism since at least the 1990s, this choice of Jameson as counterexample is understandable. "Interpretation," writes Jameson, "is here construed as essentially an allegorical act, which consists in rewriting a given text in terms of a particular interpretative master code" (Jameson 2002: $\mathrm{x})$. This programmatic definition - highlighting the necessity of "rewriting" the text's surface in order to reveal its deeper structure or 'political unconscious' - certainly makes Jameson into a key representative of what Marcus and Best conceptualize as symptomatic reading. But their engagement with Jameson appears reductive in that they leave out a key dimension of his idea of interpretation. While they take statements as the one just quoted as normative prescriptions of how the critic should engage with literary texts, what they pay less attention to are the more general hermeneutic and philosophical principles on which Jameson's perspective is based. Here, statements as the one referred to are not simply normative, for Jameson's argument is that any reading is necessarily based on certain premises - or theoretical preconceptions, codes, filters, selections, values, etc. - which is why the idea of a pure surface reading, from Jameson's perspective, would be flawed from the start. "It should not," he writes,

be necessary laboriously to argue the position that every form of practice, including the literarycritical kind, implies and presupposes a form of theory; that empiricism, the mirage of an utterly nontheoretical practice, is a contradiction in terms; that even the most formalizing kinds of literary or textual analysis carry a theoretical charge [...]. (Jameson 2002, 43)

One does not have to agree with the details of Jameson's perspective to see that this argument touches a sore spot when it comes to contemporary postcritique. From Bennett's new materialism and Felski's appropriation of Latour's network model to Marcus and Best's surface reading, there is a pronounced reluctance to reveal the theoretical premises that guide one's 'selections.' A similar point is made by Winfried Fluck, who criticizes symptomatic approaches in the style of Jameson - and in particular Jameson's reliance on the Althusserian idea of structural totality - but holds that Marcus and Best's surface approach in no way presents a proper alternative as it is marked by "a stunning hermeneutical naiveté."15 "The problem of interpretation," Fluck writes,

is that of selection (which even a 'mere' description has to make) and the principles [...] on which these selections are made. Literary theory is not the opposite to description; it is the attempt to

15 According to Fluck, this is most evident in Marcus and Best's treatment of the New Criticism: "In spite of sixty years of scholarship on the New Criticism, the authors seem to be entirely unaware of the fact that the close reading practiced by the New Criticism stood in the service of a particular aesthetic theory which made New Critics register and value certain formal properties and dismiss or ignore others." (Fluck 2014, 57) 
clarify what the principles of selection are, no matter whether the interpretive focus lies on the surface or on other levels. (Fluck 2014, 57)

In this respect, Jameson's work has the obvious advantage of displaying a form of self-reflection and transparency that is absent from most postcritical approaches. For instance, when Jameson famously claims, in the first sentence of The Political Unconscious, that literary criticism shall 'always historicize' (Jameson 2002, ix), he does so based on a specific concept of history, whose outlines and dimensions he puts up for discussion. This is strikingly different from Marcus and Best, whose own engagement with history seems largely anecdotal. When they argue, for instance, that the idea of surface reading is today an attractive mode of reading "because, at the end of the first decade of the twenty-first century, so much seems to be on the surface" (Best and Marcus 2009, 2), it appears as if the mere gesture of historicization is retained, but without any actual interest in seriously exploring historical processes. Indeed, well after postmodernism and a generation of scholars focusing on cultural or textual simulacra, and decades after the emergence of literary or artistic movements and techniques such as concrete poetry, the cut-up and fold-in technique, the nouveaux roman, pop art, photorealism, and hyperrealism, to hear literary scholars highlight the timeliness of surface reading by claiming - in 2009 - that so much these days "seems to be on the surface" may appear not only belated, but also like a fitting demonstration of the postcritical notion that 'context stinks.'16

In any case, what a more serious engagement with the history of the turn to the surface would undoubtedly have revealed is that the phenomenon is in many ways entangled with questions that postcritics typically omit, namely those pertaining to the nexus of culture and economy. In this context, the work of early twentieth-century German authors and cultural critics like Georg Simmel, Werner Sombart, Walter Benjamin, and Siegfried Kracauer is particularly illuminating. For these authors linked their own analytical interest in what Janet Ward has emblematically termed 'Weimar Surfaces' (Ward 2001) to a particular development of capitalism, one that was marked by the shop window's 'flat' aestheticization of commodities. In this early phase of consumer capitalism, many authors felt inclined to combine a phenomenological impulse to 'go back to the things themselves' (Husserl) and examine concrete, everyday surface phenomena with a keen interest in Marxism and historical

16 To underpin their argument for surface reading, Marcus and Best mention a number of political examples - like the photos of torture at Abu Ghraib that "immediately circulated on the internet" or "the real-time coverage of Hurricane Katrina" - meant to confirm that demystification as a critical strategy is nowadays "superfluous" (Best and Marcus 2009, 2). While the impact of contemporary media technology is certainly relevant here, to insinuate that because these incidents were visible, everything is, or that their sheer visibility suggests a particular hermeneutics - namely, surface reading - is an obvious generalization. (In other words, what is seen on the surface may still be unthought.) 
materialism - a tendency that is strikingly absent in the work of most contemporary postcritics. $^{17}$

Turning to a text in which the tendency to combine phenomenology and historical materialism - or surface reading and economic analysis - is especially evident, I will now briefly discuss Siegfried Kracauer's 1927 article on the 'mass ornament. ${ }^{18}$ In this mere 14-page essay, which reads today like an anticipation of Horkheimer and Adorno's Dialectic of Enlightenment (1947), Kracauer outlines a philosophy of history entailing the by now well-known idea that capitalist rationalization facilitates a possible regression from enlightenment to mythology. What is noteworthy, however, is the role Kracauer assigns to surface-level phenomena that risk getting lost in the grand narratives of historiography but are immensely valuable for historical knowledge and understanding. "The position that an epoch occupies in the historical process," Kracauer writes, "can be determined more strikingly from an analysis of its inconspicuous surface-level expressions than from that epoch's judgments about itself” (Kracauer 1995, 75). Along these lines, and somewhat similar to Walter Benjamin's description of modernity from the perspective of the flâneur, Kracauer aimed at engaging with his epoch by diagnostically 'reading' its surfaces and, in particular, everyday details, architectural features, and mass cultural phenomena (film, photography, dance, travel, advertising, department stores, hotel lobbies, etc.) that seemingly encapsulate the wider socioeconomic trends and transformations. ${ }^{19}$

In “The Mass Ornament,” Kracauer's focus lies on the precision dance routines of showgirl troupes like the Tiller Girls, whose popular revues constituted a central aspect of 1920s entertainment culture. What Kracauer finds significant about the Tiller Girls' chorus lines is how their synchronized movements and collective formation of abstract ornamental patterns resonate with the Taylorist system of industrial production: "The hands in the factory correspond to the legs of the Tiller Girls" (79). ${ }^{20}$ According to Kracauer, this analogy between popular mass culture and scientific management is plausible in that the Tiller Girls, too, embody the (Taylorist) principles and logic of instrumental rationality, real abstraction, de-individualization, and a strict division of labor: "These products of American distraction factories are no longer individual girls, but indissoluble girl clusters whose movements are demonstrations of mathematics" (75-76). Hence, comparable to the industrial worker who, under capitalist circumstances, is unable to oversee (and recognize his own role

17 Which is not to say that there are no exceptions. Cf., for example, Christopher Nealon's contribution in Marcus and Best's Representations issue (Nealon 2009).

18 I would like to thank Tanja Prokić for her helpful comments on Kracauer and 1920s visual culture. 19 Epistemologically speaking, this hermeneutical interest in details and surfaces manifests itself against the backdrop of a reinvigoration - and diversification - of physiognomic thought in the 1920s. With respect to authors like Kracauer and Benjamin, cf. Christians 2000.

20 Before Kracauer, this link had already been highlighted by Fritz Giese, whose work was located at the intersection of industrial psychology and motion study. Cf. especially his book on 'Girl Culture' (Giese 1925). 
in) the totality of the production process, the single Tiller girl is unable to behold the mass ornament as a whole and thus recognize her own role in its constitution:

Although the masses give rise to the ornament, they are not involved in thinking it through. As linear as it may be, there is no line that extends from the small sections of the mass to the entire figure. [...] The more the coherence of the figure is relinquished in favor of mere linearity, the more distant it becomes from the immanent consciousness of those constituting it. (Kracauer 1995, 77)

What, then, is the significance of this analysis from the perspective of the contemporary debate about symptomatic reading and surface reading? On the one hand, Kracauer's position must appear to the postcritic as a typical form of symptomatic reading, with the mass ornament representing merely "the aesthetic reflex of the rationality to which the prevailing economic system aspires” (79). On the other hand, however, Kracauer substantially complicates the distinction between the two kinds of hermeneutics. First off, by stating that "the aesthetic pleasure gained from ornamental mass movements is legitimate" (79), his engagement with the Tiller Girls' dance performances can hardly be swept aside as overly negative or suspicious. More important, and different from how Marcus and Best characterize symptomatic reading, Kracauer does not conceptualize the surface as hiding anything. To the contrary, what he finds valuable about the mass ornament is precisely its immediate visualization of the socioeconomic constellation. Kracauer thus argues that the mass ornament's "degree of reality is still higher than that of artistic productions which cultivate outdated noble sentiments in obsolete forms” (79):

The intellectually privileged who, while unwilling to recognize it, are an appendage of the prevailing economic system have not even perceived the mass ornament as a sign of this system. They disavow the phenomenon in order to continue seeking edification at art events that have remained untouched by the reality present in the stadium patterns. The masses who so spontaneously adopted these patterns are superior to their detractors among the educated class to the extent that they at least roughly acknowledge the undisguised facts. The same rationality that controls the bearers of the patterns in real life also governs their submersion in the corporeal. (Kracauer 1995, 85)

This passage underlines the differences between Kracauer's approach and what is typically understood as symptomatic reading. For the mass ornament is not a metaphor or allegory of the economic system; rather, it is this system - a miniature version of it. More accurately, it constitutes a section or detail of a constellation in which cultural and economic production are effectively intertwined. To highlight this constellation, Kracauer undoubtedly approaches the surfaces he studies not 'spontaneously,' but based on a number of theoretical premises, among them both Marxist and phenomenological ideas and concepts. ${ }^{21}$ Yet, while Kracauer's reliance on context analysis and historical materialism seems to be incompatible with contemporary

21 For an introduction to Kracauer's work and its intellectual influences, cf. Koch 2012. 
postcritique, his approach also differs from Jameson's insofar as he neither conceives of the mass ornament as an allegory - if we understand by it a literary device that implies some kind of substitution - nor does he engage in an actual 'rewriting.' Rather, to use Kracauer's own film-theoretical vocabulary, what he does is repeatedly switch between long shot and close-up, seeking to understand the mass ornament not as a singular, isolated phenomenon but to also grasp its particular outside: the assemblage or constellation in which it is embedded. ${ }^{22}$

\section{The Living Leviathan}

Without wishing to replicate Kracauer's critical method, but along the lines of his impulse to combine (rather than tear apart) surface and context, distance and proximity, I will now engage with an example from literary history, namely Herman Melville's Moby-Dick (1851). ${ }^{23}$ That Melville's novel lends itself to a reading in terms of the notion of poetic critique is not surprising, given that it seems to represent precisely the text Schlegel had in mind when he reflected on the concept in his review of Goethe's Wilhelm Meister. After all, with its fusion of literature and philosophy, its exuberant mix of various narrative formulas, metaphysical ideas, theological insinuations, and literary references, Moby-Dick embodies just the kind of intertextual 'critique' performed as part of a literary (i.e. 'poetic') creation Schlegel called for. And just as Wilhelm Meister comments on Shakespeare's Hamlet - thereby forming “once more what has already been formed" (Schlegel 2003, 281) - Melville's own engagement with Shakespeare's literature (especially in Moby-Dick) is a well-established fact. ${ }^{24}$

Given the novel's hypercanonization - especially in the American context, where it has long functioned as a sort of sacred text for the national imaginary - Moby-Dick has of course been read and analyzed in all kinds of fashions. And yet, the most influential readings seem to proceed in a symbolic or allegorical manner - with the whale, Ahab, the Pequod, etc. serving as symbols, conceptual personae, or metaphors that function as placeholders for something else, while the book's manifest

22 Cf. Kracauer 1969, 122: “The macro historian will falsify his subject unless he inserts the close-ups gained by the micro studies - inserts them as integrant elements of his over-all pictures. In consequence, the historian must be in a position freely to move between the macro and micro dimensions." While his books From Caligari to Hitler (1947) and Theory of Film (1960) give the most detailed account of his engagement with cinema, it is noteworthy that Kracauer frequently uses film-theoretical vocabulary - as demonstrated in the above quote - in his social and historical analyses too.

23 Some of the ideas laid out in this chapter are also discussed in two earlier publications of mine (cf. Schleusener 2011 and Schleusener 2015, 181-233).

24 Cf., for example, Matthiessen's remarks on Shakespeare's influence in his American Renaissance (Matthiessen 1968, 369-514). 
subject matter (the whale hunt) plays a minor role at best. ${ }^{25}$ Against this backdrop, my own reading attempts to take seriously what the novel says on its surface, but without neglecting to examine the text's outside. The aim here is not to pit text against context, nor is it to value content over form, but to demonstrate the impossibility of separating one from the other. ${ }^{26}$

To be sure, academic criticism has taken great pains to establish Moby-Dick as an allegorical text so as to divorce it from any sense of the merely entertaining, trivial, exotic, or adventurous - an image that Melville himself sought to get rid of after the publication of his first two novels, the much more financially successful Typee and Omoo. The notion that the white whale needs to be read as a symbol has been established ever since the 1920s, the period that saw the reappraisal of Melville's oeuvre. For instance, Melville's novel is addressed by D.H. Lawrence in his highly influential Studies in Classic American Literature. "Of course," Lawrence writes, “[Moby-Dick] is a symbol. Of what? I doubt if even Melville knew exactly” (Lawrence 1923, 214). Along similar lines, Moby-Dick was later approached in Matthiessen's American Renaissance and in the context of the myth-and-symbol school, where, against the backdrop of the Cold War, the conflict between Ishmael and Ahab was habitually read as an allegory of the conflict between American freedom and totalitarianism. ${ }^{27}$ But even after the revisionist turn and the methodological reorientation of the field (cf. Pease 1994), allegorical and symbolic readings of Moby-Dick persisted. For example, Toni Morrison analyzed the novel in the context of American race relations, arguing that the whiteness of the whale needs to be read against the backdrop of the ideology of white supremacy and the racist idealization of whiteness. Consequently, she declares Ahab to be not a "maniacal egocentric" but "the only white male American heroic enough to try to slay the monster that was devouring the world as he knew it” (Morrison 1989, 17).

Morrison's reading of Moby-Dick thus differs from older American Studies approaches in that she underlines the importance of race in Melville's writing and in-

25 While more could be said about the specific differences between allegory, symbol, and metaphor here - especially in their more complex formulation (Benjamin, Blumenberg, etc.) - such a discussion goes beyond the scope of this essay. My general point is that insofar as Moby-Dick can be said to make use of any of these literary devices, it is not based on a logic of substitution but for the sake of intensification.

26 This obviously is not a new idea, dating back at least to Hegel's reflections on "the absolute relation of content and of form" in $\S 133$ of his Encyclopedia (Hegel 2010, 200). In practice, however, critics and postcritics rarely draw the conclusions that follow from the frequently invoked inseparability of content and form: while old or new formalisms privilege form over content, much of discourse analysis and social or political criticism typically favor content over form.

27 With regard to the exceptionalist context of these readings, Donald Pease has underlined the role of Ishmael as the sole survivor of the novel's catastrophe: "That final cataclysmic image of total destruction motivated Matthiessen and forty years of Cold War critics to turn to Ishmael, who in surviving must, the logic would have it, have survived as the principle of America's freedom.” (Pease 1989, 144) 
verts the relationship between Ishmael and Ahab (now it is Ahab who, due to his readiness to combat the plague of white supremacy, is elevated to the status of American hero). What remains in place, however, is the allegorical framework as such, even though it too undergoes a noticeable revision. As Winfried Fluck has argued, revisionist approaches like Morrison's operate 'metonymically,' while the mythand-symbol critics of an earlier generation focused on what they understood to be central 'organic' metaphors (the machine in the garden, the errand into the wilderness, etc.) reflective of key facts about American culture. In Morrison's case, however, there 'is no 'organic,' metaphoric relation between the whiteness of the whale and the race problem; their 'relation' simply consists of the fact that they are both manifestations of a problem that pervades all of American society." In other words, "racism is everywhere and thus every aspect of the text can, in principle, stand for the whole” (Fluck 2014, 48).

What Fluck's analysis points to is that due to the allegorical (or metonymic) orientation of Morrison's reading, relatively little attention is given to the specificities of Moby-Dick's manifest subject matter. Hence, the equation 'whiteness of the whale' = 'the monster of racism' not only reduces the countless associations offered by Melville on the meaning of whiteness to a single signifier ('race'); it also neglects the 'whaleness' of Moby Dick and the significance of the whale's function as a nonhuman actor (to refer to Latour here for once) for Melville's dismantling of the traditional (Cartesian) subject-object relation, which is reflective of the book's central philosophical concern: that of the elusiveness of human knowledge, the withdrawal of any definitive truth, the impossibility of establishing ultimate facts about life based on mechanist systems of scientific classification. This belief - quite commonly held in the context of dark or gothic romanticism - is in Moby-Dick inextricably implicated with the world of whaling: with the narrator's cetological reflections, with his deliberations about the (more or less) 'erroneous' depictions of the whale, and with the human-animal relation in general.

With regard to the whiteness of the whale - as discussed in chapter 42 of the book (Melville 2003, 204-212) - this link between the novel's epistemological skepticism and its situatedness in the world of whaling might at first appear like an all too artificial construct. What distinguishes Moby-Dick from other whales, the readers are told, is his conspicuous white color: a whiteness that inspires Ishmael to forge a burst of associations ranging from reflections on the idea of white innocence to doubts about the adequacy of human cognition, and culminating in a general lament about "the heartless voids and immensities of the universe." Is it, he asks, that

in essence whiteness is not so much a color as the visible absence of color, and at the same time the concrete of all colors; is it for these reasons that there is such a dumb blankness, full of meaning, in a wide landscape of snows - a colorless, all-color of atheism from which we shrink? And when we [...] proceed further, and consider that the mystical cosmetic which produces every one of her hues, the great principle of light, for ever remains white or colorless in itself, and if operating without medium upon matter, would touch all objects, even tulips and roses, with its own blank tinge - pondering all this, the palsied universe lies before us a leper; and like wilful 
travellers in Lapland, who refuse to wear colored and coloring glasses upon their eyes, so the wretched infidel gazes himself blind at the monumental white shroud that wraps all the prospect around him. And of all these things the Albino whale was the symbol. (Melville 2003, 212)

Here, then, Melville himself articulates that Moby-Dick shall be read as a symbol, one that relates to the great 'inversion of light' performed in the above cited passage. From antiquity to the enlightenment, light - as the condition for rendering things visible and drawing them "out of their native darkness" (Deleuze 2008, 63) - was typically associated with knowledge, reason, consciousness, and truth. The white light on which Ishmael reflects, however, is not the light of the enlightenment. Rather, it is an essentially blinding light that obstructs any effort to obtain definitive insights, drawing attention to both the elusiveness of truth and the illusions on which human knowledge and perception are based. All this, Ishmael claims, is symbolized by the whiteness of Moby-Dick. This statement undoubtedly complicates the postcritical commitment to evade allegorical or symbolic readings and stay focused on what is present on the text's surface. For what if a text like Moby-Dick, explicitly and on its surface, tells us that the entity that gives it its title shall be taken as a symbol?

Melville's actual employment of symbolic imagery, however, is a specific and oftentimes ambiguous one. ${ }^{28}$ Obviously, Moby-Dick entails a number of elements that might at first sight lend themselves to an allegorical or symbolic reading. The whale, for instance, is persistently addressed as 'Leviathan,' a highly loaded political symbol that seems to refer to the heroic emblematics of the 'charismatic animal' (cf. Vogl 2007) rather than to the actual living creature. But while Melville is eager to include all such symbolic and allegorical dimensions as part of the polyphonic and multilayered conception of his novel, it would be a mistake to assign their use to a method of substitution. In other words, the whale in Moby-Dick is not the substitute for something else; instead, the actual animal is here related to its allegorical meanings in a weird kind of parallelism in which the meticulous, naturalistic description of the whale's massive body, "his mighty swells and undulations" (Melville 2003, 288), is consistently amplified by the mythological meaning of Leviathan as the most powerful creature of the sea. This fusion of naturalistic depiction and symbolic connotation is best highlighted when Ishmael - paradoxically - refers to the whale as "the living Leviathan" (288).

If we thus see the use of allegory and symbolism in Moby-Dick not as a form of substitution but as one of intensification, we might also get a different sense of the relationship between Ishmael and Ahab. Although the roles assigned to them differ

28 With regard to this ambiguity, cf. another passage that plainly rejects the idea of taking the white whale as an allegory: "So ignorant are most landsmen of some of the plainest and most palpable wonders of the world, that without some hints touching the plain facts, historical and otherwise, of the fishery, they might scout at Moby Dick as a monstrous fable, or still worse and more detestable, a hideous and intolerable allegory.” (Melville 2003, 223) 
from one interpretation to the next, their relationship is typically characterized as one of strict antagonism. In analogy to the parallelism between the text's manifest content and its use of symbolic imagery, however, one could also speak of a parallelism between Ishmael and Ahab. While Ahab most clearly personifies the trajectory of the actual plot - the 'manifest' hunt for the white whale - Ishmael can be said to articulate the book's 'latent' meaning in his metaphysical reflections about the elusiveness of absolute knowledge and truth. His endeavor, then, can be characterized as a hunt too. Yet, while Ahab's hunt is for the actual whale, Ishmael's is a 'hunt for knowledge,' one that is directed toward the whale as an object of science (cetology) and representation (the "monstrous" and "less erroneous" pictures of whales; cf. Melville 2003, 285-293). Different from how the book is typically interpreted, this 'parallel' reading of Moby-Dick would thus not differentiate between Ahab's sublime failure and Ishmael's fortunate survival, for both hunts - the epistemological hunt for certainty and knowledge and the physical hunt for the actual whale - are eventually unsuccessful.

Above all, what the parallel reading proposed here would underline is that the whale is certainly not a disposable vehicle merely used to transport a general message or meaning. Indeed, the latent content that Moby-Dick is assumed to entail is inextricably connected with the whale, to the effect that any meaning must necessarily 'pass through' the whale, and any effort to reveal the book's 'deeper' significance must follow the whale's own "hidden ways [...] beneath the surface" (Melville 2003, 197-198) and through "the utmost depths" (398) of the sea. For example, the critique of representation articulated in Moby-Dick is based on an understanding of the whale as a living creature with certain specific attributes and qualities that render impossible the desire for an adequate depiction. As Ishmael explains:

\begin{abstract}
Most of the scientific drawings have been taken from the stranded fish; and these are about as correct as a drawing of a wrecked ship, with broken back, would correctly represent the noble animal itself in all its undashed pride of hull and spars. Though elephants have stood for their full-lengths, the living Leviathan has never yet fairly floated himself for his portrait. The living whale, in his full majesty and significance, is only to be seen at sea in unfathomable waters. (288)
\end{abstract}

This passage underlines that the centrality of the whale in Melville's novel is by no means arbitrary or coincidental, which is why it would be impossible to subtract Moby-Dick's truth or meaning from the subject matter of whales and whaling. The novel's critique of representation, in other words - in the same way as its critique of mechanistic concepts of science - is based on a questioning of the traditional notion of the subject-object relation. According to Melville's novel, to represent or to categorize means, above all, to objectify, to turn the living whale into a "stranded fish" or "wrecked ship." It is therefore precisely Melville's discovery of the whale as a living actor - a quasi-subject possessing a particular form of knowledge and be- 
havior ${ }^{29}$ - that complicates the traditional understanding of the subject-object relation, which, in Descartes, explicitly relies on an understanding of animals as (equivalent to) machines. ${ }^{30}$ Hence, Melville's revision of the subject-object relation, in which the whale is crucially implicated, is constitutive of both Moby-Dick's critique of representation and the book's skepticism towards a certain image of scientific thought.

While this analysis seems to be fairly in line with postcritical principles - in the sense that the attention given to Moby-Dick's situatedness in the world of whaling implies an appreciation of the novel's manifest content or surface level - I will now argue that the focus on whaling will also engage the reader with precisely those aspects postcritics typically seek to omit or relativize, namely history, social context, and political economy. Of course, I do not claim that the novel's narrative is an "allegory of capitalism" (Morrison 1989, 15). What I do claim, however, is that insofar as nineteenth-century whaling is a crucial part of capitalism, this context is necessarily a fundamental aspect of Moby Dick's 'constellation.' Similar to the case of Kracauer's analysis of the mass ornament, one could thus argue that capitalism is simultaneously part of the novel's outside and inside. It constitutes the text's outside but is folded inward, so that Melville's reflections about whaling are simultaneously reflections about capitalism. Again, to grasp this constellation adequately, it is necessary to switch repeatedly from long shot to close-up and vice versa.

Hence, what needs to be kept in mind is that whaling was one of the most advanced capitalist industries of the nineteenth century, especially given the high demand for the valuable whale oil (used for lamps, among other things) before the large-scale use of petroleum initiated the gradual decline of the whaling industry. Despite the romantic notions typically associated with life on the high seas, nineteenth-century whaling in the US was thus "eerily modern [...] in the way it accumulated capital and spread risk. At a time when most of the nation's capital was dispersed in homes and on farms," whaling was "centralized," "technologically innovative," and "organizationally sophisticated” (Saunders 2004). While literature often renders the space of the sea a site of romance and adventure, this other side of the maritime experience - the sea as "a place of business" and "labor" (Jameson $2002,201)$ - is an issue in many sea novels too.

To be sure, the tension between 'romance and reification' discussed by Jameson in terms of the sea fiction of Joseph Conrad (194-270) is also a key aspect of MobyDick. After all, the original reason for the Pequod's voyage is the commercially motivated purpose of delivering whale oil to the "Nantucket market" (Melville 2003,

29 In fact, Melville repeatedly describes the knowledge of the whale as surpassing the knowledge of humans. For example, Ishmael suggests "that the Nor' West Passage, so long a problem to man, was never a problem to the whale” (Melville 2003, 198). In this context, cf. also Bühler and Rieger 2006. 30 Cf. Descartes 1998, 31: "[I]f there were such machines having the organs and the shape of a monkey or of some other animal that lacked reason, we would have no way of recognizing that they were not entirely of the same nature as these animals." 
177), an endeavor with which Ahab's desire to take revenge on Moby-Dick naturally conflicts. As Deleuze notes, Ahab breaks "the Whalers' law, which says that any healthy whale encountered must be hunted, without choosing one over another" (Deleuze 1997, 79). Above all, what Ahab's singularization of one specific whale Moby-Dick - thereby contradicts, is the capitalist logic of treating whales like a mere natural resource, whose individual parts - blubber, whale bone, sperm oil, or meat - all end up as commodities on the Nantucket market. In Moby-Dick, this economic logic of commodification evidently coincides with the sort of objectification highlighted above: the turning of the whale into an object of scientific categorization and representational depiction. Melville's critique of science is thus simultaneously a critique of capitalist reification. As Samuel Otter writes:

Melville represents the process of cutting into the skin and head of the whale as extraordinarily violent and liquid, violating the integrity of the object and threatening to inundate the observer. He associates knowledge with appropriation, representing the ways in which anatomy enables commodity and the parts of the body become vendible. (Otter 1999, 132)

But the economic context of whaling is not just reflected in Moby-Dick's narrative; it also plays a role in the novel's peculiar form. How so? Being a capitalist industry, whaling of course involves a strict division of labor, a precise timing of the work processes, a complex knowledge and understanding of these processes, and a high degree of self-discipline on the part of captain and crew. Yet, many elements of the novel contradict this tendency, especially regarding the question of temporality. What this alludes to is the untimeliness of the whale hunt - its curious situatedness at both the (dominant) center and on the (residual) fringes of nineteenth-century capitalism. For if there is an unexpected calm at sea, there is hardly anything to do on board of the ship but to exchange stories of past adventures (the famous 'seaman's yarn'). In other words, the time on board of the ship is not only the time of labor and capitalist production; it is also the time of 'the storyteller,' as one might assert with reference to Walter Benjamin's essay on the works of Nikolai Leskov. Here, Benjamin makes a sharp distinction between the novel and the "art of storytelling," the latter of which he sees "coming to an end" in the era of modern capitalism (Benjamin 2007, 83). What makes Benjamin's analysis all the more relevant with regard to Moby-Dick is that he posits the "trading seaman" (85) as one of the major sources of storytelling.

Moby-Dick, however, complicates Benjamin's distinction. More in line with Bakhtin's conception of the novel, what is characteristic about the book is its baroque heterogeneity and polyphony: the way in which it manifests itself as a proto-modernist novel but also integrates aspects of storytelling, something which becomes especially evident in those episodes where the Pequod encounters other ships, such as the Town-Ho (cf. Melville 2003, 265-284) and the Jerobeam (341-347). Here, the stories of past journeys and adventures essentially interrupt the central plot and thereby contribute to the novel's heterogenous, heterochronic, and polyphonic character. 
It can be argued, then, that part of the transgressive charm of Moby Dick - the book's multiplicity of voices, genres, narratives, and modes of communication that are only loosely kept together by the central storyline - is related to the untimely element of the whale hunt: the fact that nineteenth-century whaling was both a crucial part of the capitalist economy while simultaneously contradicting some of its central forms of organization and temporality. The whaling vessel is thus not just "the heterotopia per excellence" - as Foucault notes about the ship (Foucault 1986, 27) - but is also marked by a peculiar 'heterochronicity': the coexistence of a time of capitalist acceleration (which is also the time of the novel) with a time of boredom and relaxation (which is also the time of storytelling). ${ }^{31}$ In this sense, nineteenth-century whaling can be said to manifest an untimely tendency within capitalism, representing not so much a romantic flight away from the world as a 'line of flight' within the world, within, that is, the confines of the market.

\section{Conclusion}

In the previous chapter, I have sought to present a reading that resonates with the notion of poetic critique in (1) the attempt to bridge the alleged gap between art and criticism (demonstrated here by not so much 'judging' Moby-Dick than aiding the book in performing its own version of poetic critique); and (2) the impulse of refusing to separate the poetic and aesthetic from the critical and political. What this implies is the idea that to genuinely do justice to a literary text, it is necessary to do justice to its outside too. Here, I proposed a reading that is attentive to the text's surface and its manifest subject matter while simultaneously seeking to determine its particular constellation. As I have tried to demonstrate, this does not mean caging the text in its historical context - as if history were a "box" (Felski 2015, 154). Rather, what is significant about Moby-Dick is the book's untimeliness: the untimely way in which its form is related to mid-nineteenth-century American literature and the world of whaling it depicts was to the era's economic system. Arguably, its untimeliness is also related to why the novel continues to resonate and is time and again reactualized by the readers of a coming generation. ${ }^{32}$

31 On "boredom" and "mental relaxation" as conditions of storytelling, cf. Benjamin 2007, 91.

32 This is not to deny the role of the novel's hypercanonization in its ongoing (academic and nonacademic) popularity and relevance. It is noteworthy, however, that in American Studies Moby-Dick is among the few 'renaissance' texts that have survived the revisionist turn and are read as assiduously among 'old' as among 'new' Americanists (cf. Chase 1962 and Jehlen 1994). More recently, Moby-Dick has received much attention in the context of transnational and globalization studies (cf. Tally Jr. 2009 and Cohen 2012). 
The untimely, however, is not timelessness. ${ }^{33}$ It does not imply a movement 'out of history' (cf. Brown 2001) for it is itself a product of it. Or, as Casarino writes: "The untimely is the temporal register of that which is nonsynchronous with its own history, of that which at once is in history and yet can never completely belong to it" (Casarino 2002, xxxix-xl). Obviously, that Moby-Dick continues to be read is not unrelated to the fact that the world the novel depicts, imagines, and anticipates has something in common with 'the world we live in,' as C.L.R. James subtitled his own study about Melville in 1953. But this commonality is not to be perceived in terms of a mere resemblance or analogy. Rather, it is a question of 'resonance' (Rosa 2019), of affinities that, however timeless or universal they may appear, are still relatable to historical circumstances. In other words, if Melville's novel continues to resonate in the twenty-first century, this is not least assignable to our own historical moment's version of globalization and rootlessness, transnational commerce and mobility, waning state sovereignty and lawfulness, the commodification of 'nature' and social relations, and precarious labor conditions for a new cohort of 'mariners, renegades, and castaways' (cf. James 1953). In this respect, a "theory of attachment” (Felski 2015, 18), as called for by postcritics like Felski, will remain insufficient if it separates the affective and cognitive aspects of the reading process from their historical conditions (hence Kracauer's insistence on the combination of phenomenology and historical materialism).

The reading I proposed, then, suggests an approach aimed at working out and reactivating the political and historical implications of the text in question, yet without switching to another linguistic or semantic register, and without separating between content and form. Hence, this sort of reading is meant to constitute an alternative to both the ahistoric and descriptivistic tendencies of postcritical readings and Jameson's concept of interpretation as an allegorical rewriting (in the strict sense of the term).

But what, exactly, means 'alternative' here? This is an important point, for it underlines the way in which contemporary critical and postcritical approaches are not so different after all. Under the increasingly economized conditions of higher education and the academy, the production of theory is in some sense bound to the same market logic as is the production of other commodities. More specifically, the products of theory (concepts, turns, readings, approaches) are marked by the same logic of competition, branding, self-fashioning, distinction, acceleration, and planned obsolescence that is characteristic of today's capitalism on the whole. Whatever their particular intellectual merits, the various 'turns' (linguistic, performative, material, postcritical, speculative, descriptive, etc.) that have occurred in recent years are inextricably bound up with this context. ${ }^{34}$ Here, what is suggested is that a new meth-

33 According to Cesare Casarino, the Nietzschean notion of the untimely represents an alternative to the binary relation between "the myth of the timeless genius" and "the timely writer" who is completely determined by his historical context (Casarino 2002, xxxviii).

34 Cf. Mark Seltzer's pointed discussion of what he refers to as the "turn turn" (Seltzer 2016, 166). 
odology will make up for a lack that characterized the previous one. The new theoretical product is then typically presented in such a way as to offer a 'general alternative': an across-the-board method of reading or interpretation that ostensibly works in any case, irrespective of the nature of the specific text at hand. Along these lines, and despite the postcritical imperative to be mindful, attentive and 'do justice' to art and literature, what is hardly ever discussed is whether some texts may not deserve to be read critically and suspiciously, while others do not; or that in some cases it may be sufficient to read and 'thickly describe' the surface of a text, while other texts are designed in such a way as to necessitate being read allegorically.

Of course, the fact that I engaged with Moby-Dick to exemplify my version of a reading that circumvents the deadlocked binarism between critique and postcritique was based on the assumption that (this sort of) reading and (this sort of) text go well together. Implied in my reading is the general idea that the text should be examined in conjunction with its outside. But apart from this general commitment it is difficult to assume that the reading I proposed works with any text whatever. To be sure, this is not meant as a general call for pluralism and variation, but simply to acknowledge that different kinds of texts require different kinds of readings. Perhaps, then, what a reconsideration of Schlegel's concept of poetic critique - including his understanding of the literary text as demanding to be read "on its own terms" (Schlegel 2003, 275) - might encourage us to do is reflect more thoroughly on how our approach to literature (be it critical or poetic, postcritical or uncritical) is related to our choice of the specific texts and objects we study.

\section{Bibliography}

Anker, Elizabeth S., and Rita Felski (Eds.). Critique and Postcritique. Durham and London: Duke UP, 2017.

Benjamin, Walter. "The Storyteller. Reflections on the Works of Nikolai Leskov." Illuminations. New York: Schocken Books, 2007. 83-109.

Bennett, Jane. Vibrant Matter: A Political Ecology of Things. Durham and London: Duke UP, 2010.

Best, Stephen, and Sharon Marcus. "Surface Reading: An Introduction." Representations 108.1

(2009): 1-21.

Brown, Wendy. Politics Out of History. Princeton, NJ: Princeton UP, 2001.

Bühler, Benjamin, and Stefan Rieger. Vom Übertier: Ein Bestiarium des Wissens. Frankfurt/M.: Suhrkamp, 2006.

Casarino, Cesare. Modernity at Sea: Melville, Marx, Conrad in Crisis. Minneapolis and London: University of Minnesota Press, 2002.

Chase, Richard (Ed.). Melville: A Collection of Critical Essays. Englewood Cliffs: Prentice Hall, 1962.

Christians, Heiko. "Gesicht, Gestalt, Ornament. Überlegungen zum epistemologischen Ort der Physiognomik zwischen Hermeneutik und Mediengeschichte." Deutsche Vierteljahrsschrift für Literaturwissenschaft und Geistesgeschichte 74 (2000): 84-110.

Cohen, Margaret. The Novel and the Sea. Princeton, NJ: Princeton UP, 2012.

Deleuze, Gilles. Nietzsche and Philosophy. New York: Columbia UP, 1983. 
Deleuze, Gilles. Negotiations (1972-1990). New York: Columbia UP, 1995.

Deleuze, Gilles. Essays Critical and Clinical. Minneapolis: University of Minnesota Press, 1997.

Deleuze, Gilles. Cinema 1: The Movement Image. London and New York: Continuum, 2008.

Descartes, René. Discourse on Method and Meditations on First Philosophy. Indianapolis: Hackett Publishing Company, 1998.

Felski, Rita. Uses of Literature. Malden, MA: Blackwell, 2008.

Felski, Rita. The Limits of Critique. Chicago and London: The University of Chicago Press, 2015.

Fluck, Winfried. "Surface Readings and Symptomatic Readings: American Studies and the Realities of America." REAL. Yearbook of Research in English and American Literature 30: Towards a Post-Exceptionalist American Studies. Eds. Winfried Fluck and Donald E. Pease. Tübingen: Narr Verlag, 2014. 41-65.

Foucault, Michel. "Of Other Spaces." Diacritics 16.1 (1986): 22-27.

Foucault, Michel. The Order of Things. An Archaeology of the Human Sciences. New York: Vintage Books, 1994.

Fraser, Nancy. "From Redistribution to Recognition? Dilemmas of Justice in a 'Post-Socialist' Age." New Left Review 212 (1995): 68-93.

Giese, Fritz. Girlkultur. Vergleiche zwischen amerikanischem und europäischem Rhythmus und Lebensgefühl. Munich: Delphin Verlag, 1925.

Hegel, Georg Wilhelm Friedrich. Encyclopedia of the Philosophical Sciences in Basic Outline. Part I: Science of Logic. New York: Harvard UP, 2010.

James, C.L.R. Mariners, Renegades and Castaways: The Story of Herman Melville and the World We Live In. New York (privately printed), 1953.

Jameson, Fredric. "Cognitive Mapping." Marxism and the Interpretation of Culture. Eds. Cary Nelson and Lawrence Grossberg. Urbana and Chicago: University of Illinois Press, 1988. 347357.

Jameson, Fredric. The Political Unconscious. Narrative as a Socially Symbolic Act. London and New York: Routledge, 2002.

Jay, Martin. Marxism and Totality. The Adventures of a Concept from Lukács to Habermas. Berkeley and Los Angeles: University of California Press, 1984.

Jehlen, Myra (Ed.). Herman Melville: A Collection of Critical Essays. Englewood Cliffs: Prentice Hall, 1994.

Koch, Gertrud. Siegfried Kracauer zur Einführung. Hamburg: Junius, 2012.

Kracauer, Siegfried. History. The Last Things Before the Last. New York: Oxford UP, 1969.

Kracauer, Siegfried. "The Mass Ornament." The Mass Ornament: Weimar Essays. Cambridge and London: Harvard UP, 1995. 75-86.

Latour, Bruno. The Pasteurization of France. Cambridge and London: Harvard UP, 1993.

Latour, Bruno. Reassembling the Social: An Introduction to Actor-Network-Theory. Oxford and New York: Oxford UP, 2005.

Lawrence, D.H. Studies in Classic American Literature. New York: Thomas Seltzer, 1923.

Love, Heather. "Close but not Deep: Literary Ethics and the Descriptive Turn." New Literary History 41 (2010): 371-391.

Matthiessen, F.O. American Renaissance: Art and Expression in the Age of Emerson and Whitman. Oxford and New York: Oxford UP, 1968.

Melville, Herman. Moby-Dick; or, The Whale. London: Penguin, 2003.

Michaels, Walter Benn. The Trouble with Diversity. How We Learned to Love Identity and Ignore Inequality. New York: Henry Holt, 2006.

Mitchell, Timothy. Carbon Democracy. Political Power in the Age of Oil. London and New York: Verso, 2013.

Moretti, Franco. Distant Reading. London and New York: Verso, 2013. 
Morrison, Toni. "Unspeakable Things Unspoken: The Afro-American Presence in American Literature." Michigan Quarterly Review 28.1 (Winter 1989): 1-34.

Nealon, Christopher. "Reading on the Left." Representations 108.1 (2009): 22-50.

Noys, Benjamin. The Persistence of the Negative. A Critique of Contemporary Continental Theory. Edinburgh: Edinburgh UP, 2010.

Noys, Benjamin. "The Hammer of the Gods: Critique, After All." The Value of Critique: Exploring the Interrelations of Value, Critique, and Artistic Labour. Eds. Isabelle Graw and Christoph Menke. Frankfurt/M. and New York: Campus Verlag, 2019. 31-43.

Otter, Samuel. Melville's Anatomies. Berkeley, Los Angeles, and London: University of California Press, 1999.

Pease, Donald. "Moby Dick and the Cold War." The American Renaissance Reconsidered. Eds. Walter Benn Michaels and Donald Pease. Baltimore and London: Johns Hopkins UP, 1989. 113-155.

Pease, Donald. "New Americanists: Revisionist Interventions into the Canon." Revisionary Interventions into the Americanist Canon. Ed. Donald E. Pease. Durham and London: Duke UP, 1994. 1-37.

Ricœur, Paul. Freud and Philosophy: An Essay on Interpretation. New Haven and London: Yale UP, 1970.

Robbins, Bruce. "Not So Well Attached." PMLA 132.2 (2017): 371-376.

Rosa, Hartmut. Resonance: A Sociology of Our Relationship to the World. Cambridge: Polity Press, 2019.

Saunders, Laura. "Blubber Capitalism." Forbes (11 October 2004). http://www.forbes.com/forbes/ 2004/1011/096.html (14 June 2020).

Schlegel, Friedrich. "On Goethe's Meister." Classic and Romantic German Aesthetics. Ed. J. M. Bernstein. Cambridge: Cambridge UP, 2003. 269-286.

Schleusener, Simon. "Sovereignty at Sea: Moby Dick and the Politics of Desire." REAL: Yearbook of Research in English and American Literature 27: States of Emergency - States of Crisis. Eds. Winfried Fluck, Katharina Motyl, Donald E. Pease, and Christoph Raetzsch. Tübingen: Narr Verlag, 2011. 121-142.

Schleusener, Simon. Kulturelle Komplexität: Gilles Deleuze und die Kulturtheorie der American Studies. Bielefeld: transcript, 2015.

Schleusener, Simon. "Das Außerhalb des Textes: Literaturtheorie nach Derrida und Deleuze." (Paper given at the conference Philologie und Kritik, Freie Universität Berlin, 22 June 2018 [2018a]). https://www.academia.edu/36915844/Das_Außerhalb_des_Textes_Literaturtheorie_ nach_Derrida_und_Deleuze (14 June 2020).

Schleusener, Simon. "Post-Truth Politics: The New Right and the Postmodern Legacy." Modernities and Modernization in North America. Eds. Ilka Brasch and Ruth Mayer. Heidelberg: Universitätsverlag Winter, 2018b. 353-370.

Sedgwick, Eve Kosofsky. "Paranoid Reading and Reparative Reading, or, You're so Paranoid, You probably Think This Essay Is About You." Touching Feeling. Affect, Pedagogy, Performativity. Durham and London: Duke UP, 2003. 123-151.

Sedgwick, Eve Kosofsky. "Queer Performativity: Henry James's The Art of the Novel." The Novel: An Anthology of Criticism and Theory, 1900-2000. Ed. Dorothy J. Hale. Malden: Blackwell Publishing, 2006. 605-620.

Sedgwick, Eve Kosofsky, and Adam Frank. "Shame in the Cybernetic Fold: Reading Silvan Tomkins." Critical Inquiry 21.2 (1995): 496-522.

Seltzer, Mark. The Official World. Durham and London: Duke UP, 2016.

Tally Jr., Robert T. Melville, Mapping and Globalization: Literary Cartography in the American Baroque Writer. London and New York: Continuum, 2009. 
Taylor, Charles. Multiculturalism and the Politics of Recognition: An Essay. Princeton: Princeton UP, 1992.

Toscano, Alberto, and Jeff Kinkle. Cartographies of the Absolute. Winchester and Washington: Zero Books, 2015.

Vogl, Joseph. "Das charismatische Tier." Politische Zoologie. Eds. Anne von der Heiden and Joseph Vogl. Zurich and Berlin: Diaphanes, 2007. 119-130.

Wallerstein, Immanuel. World-Systems Analysis: An Introduction. Durham: Duke UP, 2004.

Ward, Janet. Weimar Surfaces: Urban Visual Culture in 1920s Germany. Berkeley and Los Angeles: University of California Press, 2001.

Zamora, Daniel, and Michael C. Behrent (Eds.). Foucault and Neoliberalism. Cambridge and Malden: Polity Press 2016. 
